\title{
Digestion of bacteria by the freshwater ciliate Tetrahymena pyriformis
}

\author{
J. Thurman, J. Drinkall, J. D. Parry* \\ School of Health and Medicine, Division of Biomedical and Life Sciences, Lancaster University, Lancaster, LA1 4 YQ, UK
}

\begin{abstract}
The digestion of heat-killed/stained Escherichia coli, Pseudomonas aeruginosa, Mesorhizobium sp. and Staphylococcus aureus was monitored within one food vacuole passage time in the ciliate Tetrahymena pyriformis using the pulse chase technique. Prey digestion proceeded in 2 phases: a digestive phase which lasted $\sim 25 \mathrm{~min}$ and a defecation competent phase that showed limited digestive activity and was variable in length. The number of prey cells per food vacuole was found to influence the effectiveness of prey digestion. Complete digestion of the vacuole content was more likely to occur when the number of prey per vacuole averaged $\sim 6$ or less. At higher levels, only partial digestion of the vacuole content was recorded and some undigested prey were egested from the ciliate cell. A strain of Synechococcus sp. was never digested by this ciliate. Results suggest that bacteria do not necessarily require elaborate mechanisms to evade digestion by protozoa, as possessed by some pathogenic bacteria, but that inefficiency in the protozoan digestive system is all that is required to allow the release of undigested, apparently unharmed prey from their cells. Thus, models on carbon cycling which employ data on protistan ingestion rates alone should consider accounting for digestion efficiency and the subsequent effect of prey concentration, because prey carbon might not always be transferred efficiently to higher trophic levels.
\end{abstract}

KEY WORDS: Protozoa $\cdot$ Ingestion $\cdot$ Egestion $\cdot$ Phagosome $\cdot$ Feeding-history

\section{INTRODUCTION}

Protozoa are important bacterivores in aquatic environments, making a significant contribution to the transfer of bacterial carbon to higher organisms (Azam et al. 1983) and in the regeneration of inorganic nutrients (Johannes 1964). However, this predator-prey relationship is complex as some bacteria can prevent normal digestive processes within protozoan food vacuoles (Abu Kwaik et al. 1998, Strahl et al. 2001), whilst others can undergo the full digestive process and emerge apparently unharmed (Schlimme et al. 1995, 1997, Pickup et al. 2007, Dillon \& Parry 2009). This latter phenomenon is poorly understood and may be a result of an active response by bacteria, as it is for pathogens (Abu Kwaik et al. 1998), or selective or inefficient digestion by protozoa (González et al. 1990).

Prey digestion has been assessed using the pulse chase technique (Sherr et al. 1988, González et al. 1990, 1993, Dolan \& Coats 1991, 2008, González \&
Suttle 1993, Iriberri et al. 1994, Dolan \& Šimek 1997 , 1998, Gunderson \& Goss 1997, Jürgens \& Šimek 2000, Hammer et al. 2001, Jezbera et al. 2005, Myung et al. 2006). This methodology permits protozoa to be 'pulsed' with a fluorescent prey, allowing for the formation of labeled food vacuoles, and then the suspension is 'chased' by dilution to significantly reduce further labeled vacuole formation. The number of fluorescent prey/vacuoles within the protozoan cells is then monitored over time to observe vacuole processing and prey loss. The use of indigestible prey allows the total lifespan of vacuoles to be identified, i.e. from vacuole formation to vacuole 'egestion': a period known as the vacuole passage time (VPT). As no egestion of vacuolar content occurs within the VPT, any loss of potentially digestible prey during this period is interpreted as being due to digestion only. Beyond the identified VPT, any observed loss of prey might be due to a combination of digestion and egestion. 
Fok et al. $(1982,1984)$ proposed that distinct phases of digestion and non-digestion occur within the VPT of the ciliate Paramecium caudatum. The length of the initial digestive phase was found to be constant ( 21 min) and was divided into vacuole formation, acidification and condensation, and lysosomal fusion. The defecation competent phase, where vacuoles exhibit no digestion and are waiting to be expelled, was found to be highly variable. Defecation competent vacuoles have also been noted in the raptorial ciliate Litonotus lamella, after a digestive phase of $1 \mathrm{~h}$ (Verni \& Gualtier 1997). These data suggest that the digestive phase might be constant for a given ciliate but that the defecation competent phase is variable, reasons for which have yet to be proposed.

The present study examined the processing of food vacuoles in the freshwater ciliate Tetrahymena pyriformis. The length of the VPT was determined from the processing of 2 indigestible prey, i.e. fluorescent microspheres and cells of the freshwater picocyanobacterium Synechococcus sp. The ability of this ciliate to digest 4 species of heat-killed, fluorescently-labeled bacterial cells was then evaluated to determine the length of the digestive phase, whether differential digestion of the 4 prey occurred and whether ciliate feeding history affected digestion rates.

\section{MATERIALS AND METHODS}

Ciliate and prey maintenance and preparation. Tetrahymena pyriformis: T. pyriformis (Culture Collection of Algae and Protozoa [CCAP] 1630/1W) was grown for $3 \mathrm{~d}$ in Chalkley's medium (CCAP) supplemented with live Mesorhizobium sp. (formally bacterium B1, Eccleston-Parry \& Leadbeater, 1994) at $20^{\circ} \mathrm{C}$. Cultures were concentrated by centrifugation $(185 \times g$ for $10 \mathrm{~min})$, incubated overnight at $20^{\circ} \mathrm{C}$ and acclimated to $23^{\circ} \mathrm{C}$ for $2 \mathrm{~h}$ prior to experimentation at this temperature. Mesorhizobium sp. concentration ('background bacterium') was determined by 4',6diamidino-2-phenylindole (DAPI) staining and epifluorescence microscopy (UV excitation; BP340$380 \mathrm{~nm} / \mathrm{LP} 430 \mathrm{~nm}$ filter block) (Porter \& Feig 1980).

Indigestible prey: Suspensions of carboxylated fluorescently-labelled microspheres (yellow, 0.49 or $0.92 \mu \mathrm{m} \pm 0.01$ [SE] diameter or blue $0.48 \mu \mathrm{m} \pm 0.01 \mathrm{di}-$ ameter) (Fluoresebrite ${ }^{\mathrm{TM}}$ Polysciences) were prepared in Chalkley's medium and stored at $4^{\circ} \mathrm{C}$. Particle concentrations were determined with blue excitation (BP350-460 nm/LP515 nm filter block) and UV excitation, for yellow and blue microspheres respectively. Synechococcus sp. S-KH5 (Dillon \& Parry 2008) was grown in BG11 broth (Stanier et al. 1971) in a 16:8 light:dark cycle at $23^{\circ} \mathrm{C}$ under constant rotation. Cells were harvested at $14 \mathrm{~d}$, concentrated by centrifugation $(2955 \times g$ for $10 \mathrm{~min})$ and re-suspended in Chalkley's medium. No staining of Synechococcus sp. was required due to its inherent chlorophyll a fluorescence under green excitation (BP530-560 nm/LP580 nm filter block).

Digestible prey: Escherichia coli K12 (CCAP/10214), Pseudomonas aeruginosa SG81 (H-C Fleming, Gerhard Mercator University, Germany), Staphylococcus aureus (National Collection of Type Cultures [NCTC] 6571) and Mesorhizobium sp. were grown on nutrient agar (Lab M) at $25^{\circ} \mathrm{C}$ for $5 \mathrm{~d}$ prior to making cell suspensions in Chalkley's medium and heat-killing at $60^{\circ} \mathrm{C}$ for $2 \mathrm{~h}$ in the presence of 5-([4,6-dichloro-triazin2-yl]amino) fluorescein (DTAF) following Sherr et al. (1987). Before use, all prey types were sonicated for $10 \mathrm{~min}$ and cell concentrations were determined by epifluorescence microscopy (blue excitation).

Vacuole passage time determined by single pulse chase experiments. The nature of vacuole processing was investigated using indigestible prey over a range of initial prey concentrations (e.g. see Table 1: microspheres). One such experiment is described here in detail: $2 \mathrm{ml}$ aliquots of a Tetrahymena pyriformis culture were inoculated with either yellow microspheres (0.92 \pm 0.01 [SE] $\mu \mathrm{m}$ diameter) or Synechococcus sp. cells (1.12 $\pm 0.014 \mu \mathrm{m}$ diameter) at $2 \times 10^{7}$ prey $\mathrm{ml}^{-1}$, in triplicate. The background bacterial concentration was $1.01 \times 10^{7}$ cells $\mathrm{ml}^{-1}$, so the fluorescent prey represented $66 \%$ of the total prey. At $20 \mathrm{~min}$, the mixture was diluted 1:1000 in Chalkley's medium supplemented with live 'invisible' Mesorhizobium sp. at $3.01 \times 10^{7}$ cells ml $^{-1}$ to replace the initial background bacterial and fluorescent marker prey concentrations. The fluorescent prey was thus decreased $(<0.1 \%$ of total prey) and this reduced further uptake by the ciliate. Sub-samples were removed at defined time intervals $(200 \mu \mathrm{l}$ predilution and $1 \mathrm{ml}$ post-dilution) and fixed in $1 \%$ (final v/v) ice-cold glutaraldehyde. Cells were viewed with epifluorescence microscopy (magnification $\times 1250$ ), and even though glutaraldehyde possesses an inherent autofluorescence (Sanders et al. 1989), prey were easily visualised within the food vacuoles. Between 20 and 30 ciliate cells were examined for each replicate sample and the number of fluorescent vacuoles cell ${ }^{-1}$ recorded. Controls were included to monitor the level of residual ingestion of fluorescent prey after the chase, following González et al. (1993). Non-exposed T. pyriformis cultures were incubated with fluorescent prey and live Mesorhizobium sp. at equivalent concentrations to those present in the test suspensions after dilution. Subsamples were removed, fixed and the number of labeled food vacuoles cell ${ }^{-1}$ was enumerated in the same way as in the test cultures.

Multiple pulse chase experiments. To observe the order in which food vacuoles are processed inside 
Tetrahymena pyriformis, $2 \mathrm{ml}$ of culture was pulsed with blue microspheres for $5 \mathrm{~min}$, in triplicate, at $2 \times$ $10^{8}$ particles $\mathrm{ml}^{-1}$ to allow formation of blue primary food vacuoles. The culture was then diluted 10 -fold into Chalkley's medium containing yellow microspheres at $2 \times 10^{8}$ particles $\mathrm{ml}^{-1}$ for $5 \mathrm{~min}$ to allow formation of yellow secondary food vacuoles. At $10 \mathrm{~min}$, the culture was diluted 1:40 into Chalkley's medium containing live Mesorhizobium sp. at $2 \times 10^{8}$ cells ml $^{-1}$ to produce tertiary 'invisible' vacuoles. The persistence of yellow and blue vacuoles was monitored using 2 methods. (1) Fixed method: sub-samples were removed and fixed with ice-cold glutaraldehyde (1\% final v/v) at predetermined intervals. Between 20 and 30 cells in each replicate were examined for the presence of yellow and/or blue vacuoles using epifluorescence microscopy (magnification $\times 1250$ ). (2) Live monitoring: from previous experiments, the start of egestion was expected at some point $30 \mathrm{~min}$ after the initial feed, so at $30 \mathrm{~min}$, $20 \mu \mathrm{l}$ of the culture was placed on a microscope slide with $10 \mu$ l of $10 \%$ Pluoronic F-68 solution (Sigma). Carefully, $3 \%$ alginic acid sodium salt (Fluka) was added to slow ciliate motility and cause egested food vacuoles to 'cling' to some of the ciliates' cytoproct. Pluoronic F-68 prolonged the life-span of cells within the viscous alginate (Hellung-Larsen et al. 2000). The cells were observed with epifluorescent microscopy (magnification $\times 500$ ) to deduce the order in which vacuoles were egested from cells and whether 2 vacuoles fused and were 'egested' simultaneously.

Digestion experiments. Pulse-chase experiments were performed using different concentrations of DTAF-stained Escherichia coli K12, Mesorhizobium sp., Pseudomonas aeruginosa and Staphylococcus aureus. In each case, controls employing an equivalent concentration of an indigestible prey ran alongside, to identify the length of the VPT. Cultures were pulsed for 5 min then diluted 1:200 in Chalkley's medium supplemented with the live unstained counterpart. Microspheres and Synechococcus sp. cells were replaced with Mesorhizobium sp. Samples were removed, fixed and 20 to 30 cells per replicate were viewed with epifluorescence microscopy as described above. Both the number of prey cell ${ }^{-1}$ and number of vacuoles cell ${ }^{-1}$ were recorded. Controls were included to monitor the level of residual ingestion after dilution.

Effect of ciliate feeding history. Tetrahymena pyriformis was pre-fed either live Mesorhizobium sp., Synechococcus sp. or blue microspheres at $2 \times 10^{7}$ particles $\mathrm{ml}^{-1}$ for 5, 15 and 30 min prior to performing a pulse-chase experiment with DTAF-stained Mesorhizobium sp. Those populations fed with Mesorhizobium sp. were considered well fed for 5, 15 and $30 \mathrm{~min}$ and would contain different numbers of food vacuoles containing live digestible prey prior to the pulse chase experiment. Those fed with Synechococcus sp./microspheres were considered starved for 5, 15 and $30 \mathrm{~min}$ and would contain different numbers of food vacuoles containing live/inert indigestible prey. A T. pyrifomis culture, which had not been pre-fed and would contain the least number of food vacuoles prior to experimentation, acted as the control. Each of the pre-fed populations (with their pre-existing food vacuoles), were immediately subjected to dilution (1:10) into Chalkley's medium containing fluorescent Mesorhizobium sp. at $2 \times 10^{7}$ cells $\mathrm{ml}^{-1}$, together with non-fluorescent Mesorhizobium sp. to replace the background bacteria $\left(1.35 \times 10^{7}\right.$ cells $\left.\mathrm{ml}^{-1}\right)$. After $5 \mathrm{~min}$, the cultures were diluted (1:50) in Chalkley's medium supplemented

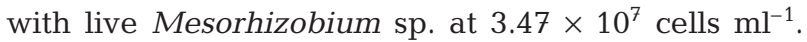
The persistence of the fluorescent Mesorhizobium sp. was monitored over time and the digestion rate (prey vacuole $^{-1} \mathrm{~min}^{-1}$ ) was deduced within $1 \mathrm{VPT}$, with the VPT being defined as the time the first pre-existing fluorescent food vacuole (containing microspheres or Synechococcus cells) was lost from the cells.

Interpretation of data. Graphs were plotted of prey cell $^{-1}$ and vacuoles cell ${ }^{-1}$ against time (min) and linear regression analysis of the increasing slopes between time $(\mathrm{t})=0$ and the point of dilution yielded ingestion rates and vacuole formation rates, respectively. The length of VPT was deduced from the onset of the loss of the indigestible particles from the cells. Prey egestion rates were determined from linear regression analysis of the decreasing slope of indigestible particles cell ${ }^{-1}$, beyond the VPT. Vacuole 'egestion' rates were also determined this way, although strictly speaking, vacuoles are not egested from the cells (only their contents), as vacuole membrane is recycled to make new vacuoles (Allen \& Fok 1980).

In digestion experiments, for each ciliate cell, the number of prey cell ${ }^{-1}$ was divided by the number of vacuoles cell ${ }^{-1}$ to give the number of prey vacuole ${ }^{-1}$, and the rate of digestion was calculated from the linear decline in prey vacuole $^{-1}$ from the point of dilution ( $5 \mathrm{~min}$ ) to $25 \mathrm{~min}$. Although rates of digestion can be expressed as loss of prey cell ${ }^{-1}$, its use to evaluate differential digestion is only valid if the different prey give rise to equivalent numbers of vacuoles. If some prey promotes higher numbers of vacuoles, then higher rates of digestion may be calculated, and this is misleading as it is a result of simultaneous digestion in all the vacuoles. The loss of prey vacuole ${ }^{-1}$ provides a better indication of differential digestion between prey types, but these data are difficult to correct for residual ingestion. Generally a high dilution minimises residual ingestion, but each experiment must be considered on its own merit.

The overall fate of enclosed prey within food vacuoles was characterised as being (1) not digested (ND), 
(2) partially digested (PD) or (3) totally digested (TD) within $1 \mathrm{VPT}$, using the following set of criteria, respectively: if there was no loss in both prey cell ${ }^{-1}$ and vacuoles cell ${ }^{-1}$, the vacuole contents were considered to be ND. If there was a loss in prey cell ${ }^{-1}$, but no loss of vacuoles cell ${ }^{-1}$, this indicated that the vacuole contents were PD and the number of fluorescent food vacuoles remained constant due to the presence of some undigested fluorescent prey within them. A loss of both prey cell ${ }^{-1}$ and vacuoles cell ${ }^{-1}$ indicated the vacuole contents were TD, and because of this, food vacuoles became 'invisible'.

All linear regression analyses were performed on each triplicate data set using SPSS statistics package 15.0. These rates were then averaged to produce mean rates. Differences between means were detected by one-way ANOVAs and further identified by post-hoc Tukey's test or Student's $t$-test.

\section{RESULTS}

\section{Processing of food vacuoles}

The nature of food vacuole processing in Tetrahymena pyriformis was investigated using indigestible prey so the full life-span of the vacuoles could be monitored. Fig. 1 shows an example of the results obtained for this ciliate feeding on either yellow microspheres or Synechococcus sp. cells (as described in 'Materials and methods'). During the pulse, vacuole formation rates were $0.231 \pm 0.005(\mathrm{SE})$ and $0.444 \pm 0.017$ vacuoles cell $^{-1} \mathrm{~min}^{-1}$ for microspheres and Synechococcus sp.

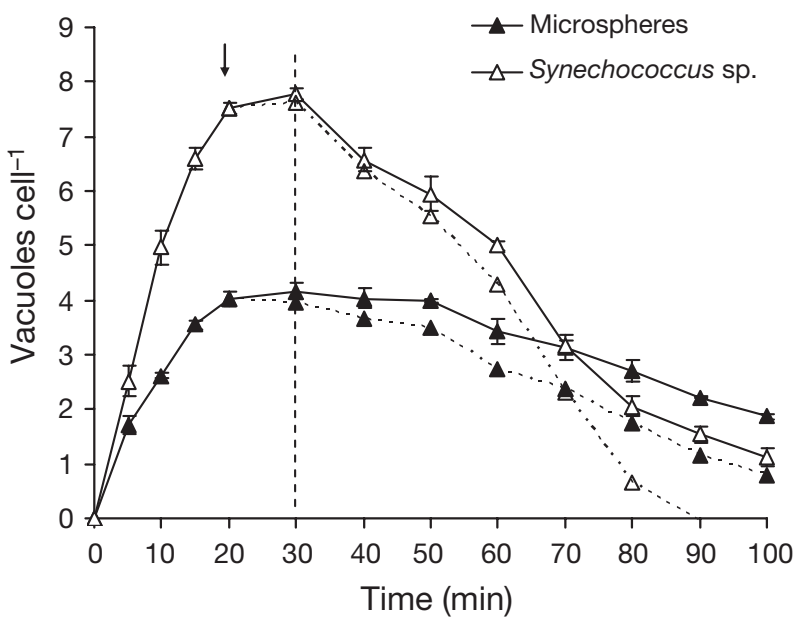

Fig. 1. Tetrahymena pyriformis. Processing of vacuoles containing non-digestible prey. Prey were incubated at a concentration of $2 \times 10^{7} \mathrm{prey} \mathrm{m}^{-1}$. Arrow shows 1:1000 dilution. Vacuole passage time: time when vacuole number starts to decreases linearly (vertical hashed line). Both observed (unbroken lines) and corrected data for residual ingestion (broken lines) are shown. Error bars: SE cells respectively, which are significantly different $(\mathrm{p}=$ 0.003). At $20 \mathrm{~min}$, the culture was diluted 1:1000 into Chalkley's medium containing 'invisible' Mesorhizobium sp. Although this significantly reduced the uptake of residual fluorescent prey, data were still corrected (Fig. 1 dotted lines). The number of fluorescent vacuoles cell ${ }^{-1}$ remained relatively constant for a further $10 \mathrm{~min}$ (Fig. 1 vertical hashed line) before the onset of linear egestion. The VPT was thus identified as being $30 \mathrm{~min}$; however, VPTs did differ between experiments and ranged from 25 to $55 \mathrm{~min}$. Because of this, all digestion experiments included an indigestible prey to identify the length of the VPT.

Linear egestion (Fig. 1 dotted lines) suggests that food vacuoles are processed in an orderly manner, and this was confirmed in the multiple-chase experiment. Fig. 2a shows the percentage of ciliate cells containing (1) no fluorescent vacuoles, (2) blue vacuoles only, (3) yellow vacuoles only or, (4) both blue vacuoles and yellow vacuoles, throughout the experiment. The ciliates
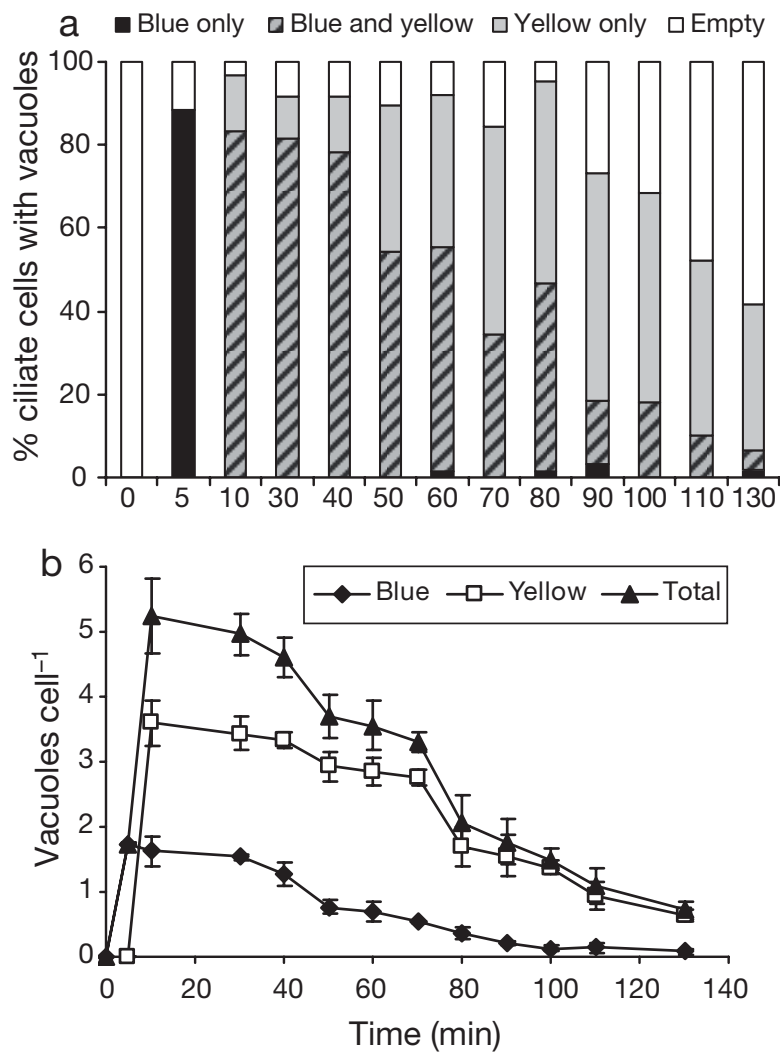

Fig. 2. Tetrahymena pyriformis. Multiple pulse chase experiment. Ciliates were incubated with blue microspheres for 5 min, followed by a 1:10 dilution and pulsed with yellow microspheres. At $\mathrm{t}=10 \mathrm{~min}$, the culture was diluted 1:40 and fluorescent prey replaced with Mesorhizobium sp. (a) \% ciliates containing only blue vacuoles, only yellow vacuoles, both blue vacuoles and yellow vacuoles or those devoid of fluorescent vacuoles. (b) persistence of blue, yellow and total vacuoles over time (error bars: SE) 
were initially fed with blue microspheres for 5 min and $\sim 90 \%$ of the cells ingested this prey, forming blue primary vacuoles (Fig. 2a). At $5 \mathrm{~min}$, the culture was diluted in Chalkley's medium containing yellow microspheres and by $10 \mathrm{~min}, 85 \%$ of the cells contained both yellow secondary vacuoles and blue primary vacuoles (Fig. 2a). At $10 \mathrm{~min}$, the culture was diluted 1:40 with live Mesorhizobium sp. to produce 'invisible' tertiary vacuoles, and although these contained mainly Mesorhizobium sp. cells, they did contain a low level of fluorescent prey due to residual ingestion following the chase. However, these vacuoles were easily identified and their persistence in the cell was not monitored.

The vacuole profile of the ciliate population ( $80 \%$ both, $15 \%$ yellow only, $5 \%$ none, Fig. 2 a) and the number of fluorescent vacuoles cell ${ }^{-1}$ (Fig. 2b) remained relatively unaltered until $40 \mathrm{~min}$. We take this to indicate the end of the VPT and the start of egestion sometime between 40 and $50 \mathrm{~min}$. At this point, the \% cells containing both vacuole colours started to decrease while those containing only yellow vacuoles increased, suggesting that blue were being 'egested' and that some cells, which originally contained both vacuole colour types, now only contained yellow vacuoles (Fig. 2a). This pattern continued until the \% cells with no fluorescent vacuoles began to increase sometime between 80 and $90 \mathrm{~min}$, indicating that yellow vacuoles were now being 'egested', some 40 min after the first release of blue vacuoles. The VPT for the younger yellow vacuoles was therefore 75 to $85 \mathrm{~min}$ : $35 \mathrm{~min}$ longer than the VPT of the older blue vacuoles (40 to $50 \mathrm{~min}$ ). This shows that vacuole 'egestion' was an orderly process and that the yellow vacuoles were queuing behind the blue vacuoles before they could be 'egested' from the cytoproct.
Another feature common to all the experiments was that vacuole 'egestion' rates were slower than their corresponding formation rates (e.g. Fig. 1, Table 1), due to the cells not being in steady-state within batch culture experiments. Vacuole 'egestion' rates were also invariable with initial prey concentration, provided the vacuoles contained the same prey type, i.e. microspheres (Table 1), where the average vacuole 'egestion' rate was $0.046 \pm 0.026(\mathrm{SE})$ vacuoles cell ${ }^{-1} \mathrm{~min}^{-1}$. However, 'egestion' rate can vary if the vacuoles contain different prey and the 'egestion' rate of microsphere-containing vacuoles $\left(0.049 \pm 0.002\right.$ vacuoles cell $\left.{ }^{-1} \mathrm{~min}^{-1}\right)$ was significantly lower than the 'egestion' rate of Synechococcus sp.-containing vacuoles $(0.137 \pm 0.004$ vacuoles cell $^{-1}$ ) (Fig. 1); the reason for this variation is currently unknown. Even so, vacuole content did not appear to affect the duration of the VPT, as all experiments have yielded equivalent VPTs when both microspheres and Synechococcus cells are used (e.g. see Figs. 1 \& 5a).

\section{Defining the length of the digestive phase within food vacuoles}

Fig. 3 shows an example of a Tetrahymena pyriformis pulse-chase experiment that employed yellow microspheres (to define the VPT) and 2 potentially digestible bacteria (Staphylococcus aureus and Pseudomonas aeruginosa). The 1:200 dilution at $5 \mathrm{~min}$ reduced further ingestion of fluorescent prey, and residual ingestion did not yield rates which significantly changed the data, so the data were not corrected for (as in Fig. 1). The VPT was $40 \mathrm{~min}$ in this experiment (Fig. 3a), so the loss of digestible prey was only monitored between 5 and $40 \mathrm{~min}$, when egestion was known not to be occurring. Prey loss cell ${ }^{-1}$ was not

Table 1. Tetrahymena pyriformis. Ingestion, vacuole formation and egestion rates $\pm \mathrm{SE}$ of prey/vacuoles when fed microspheres at various initial concentrations. ND: not determined

\begin{tabular}{|c|c|c|c|c|c|}
\hline $\begin{array}{l}\text { Microsphere } \\
\text { concentration } \\
\left(\text { prey } \mathrm{ml}^{-1}\right)\end{array}$ & $\begin{array}{l}\text { Microsphere } \\
\text { diameter }(\mu \mathrm{m})\end{array}$ & $\begin{array}{c}\text { Ingestion rate } \\
\left(\text { prey cell }{ }^{-1} \mathrm{~min}^{-1}\right)\end{array}$ & $\begin{array}{l}\text { Vacuole formation } \\
\text { rate (vacuole cell } \\
\text { (-1 } \\
\left.\text { min }^{-1}\right)\end{array}$ & $\begin{array}{l}\text { Prey egestion rate } \\
\left(\text { prey cell }{ }^{-1} \mathrm{~min}^{-1} \text { ) }\right.\end{array}$ & $\begin{array}{l}\text { Vacuole egestion rate } \\
\text { (vacuole cell }{ }^{-1} \mathrm{~min}^{-1} \text { ) }\end{array}$ \\
\hline $1.5 \times 10^{6}$ & 0.49 & ND & $0.12 \pm 0.01$ & ND & $0.03 \pm 0.00$ \\
\hline $4.5 \times 10^{6}$ & 0.49 & ND & $0.23 \pm 0.01$ & ND & $0.04 \pm 0.00$ \\
\hline $7.3 \times 10^{6}$ & 0.49 & ND & $0.29 \pm 0.02$ & ND & $0.06 \pm 0.00$ \\
\hline $1.0 \times 10^{7}$ & 0.49 & ND & $0.25 \pm 0.03$ & ND & $0.09 \pm 0.01$ \\
\hline $1.0 \times 10^{7}$ & 0.49 & $2.58 \pm 0.32$ & $0.41 \pm 0.05$ & $0.12 \pm 0.01$ & $0.02 \pm 0.00$ \\
\hline $1.5 \times 10^{7}$ & 0.49 & ND & $0.34 \pm 0.01$ & ND & $0.08 \pm 0.01$ \\
\hline $2.0 \times 10^{7}$ & 0.49 & $4.73 \pm 0.17$ & $0.57 \pm 0.04$ & $0.20 \pm 0.06$ & $0.02 \pm 0.00$ \\
\hline $2.0 \times 10^{7}$ & 0.49 & $5.24 \pm 0.33$ & $0.55 \pm 0.05$ & $0.23 \pm 0.02$ & $0.01 \pm 0.00$ \\
\hline $2.0 \times 10^{7}$ & 0.92 & ND & $0.23 \pm 0.01$ & ND & $0.05 \pm 0.00$ \\
\hline $1.9 \times 10^{8}$ & 0.49 & ND & $0.78 \pm 0.05$ & ND & $0.08 \pm 0.01$ \\
\hline $2.0 \times 10^{8}$ & 0.49 & $7.72 \pm 0.37$ & $0.44 \pm 0.01$ & $0.75 \pm 0.09$ & $0.03 \pm 0.00$ \\
\hline $2.0 \times 10^{8}$ & 0.92 & $6.81 \pm 0.41$ & $0.65 \pm 0.01$ & $0.32 \pm 0.01$ & $0.03 \pm 0.01$ \\
\hline $2.1 \times 10^{8}$ & 0.49 & ND & $0.64 \pm 0.03$ & ND & $0.06 \pm 0.00$ \\
\hline
\end{tabular}



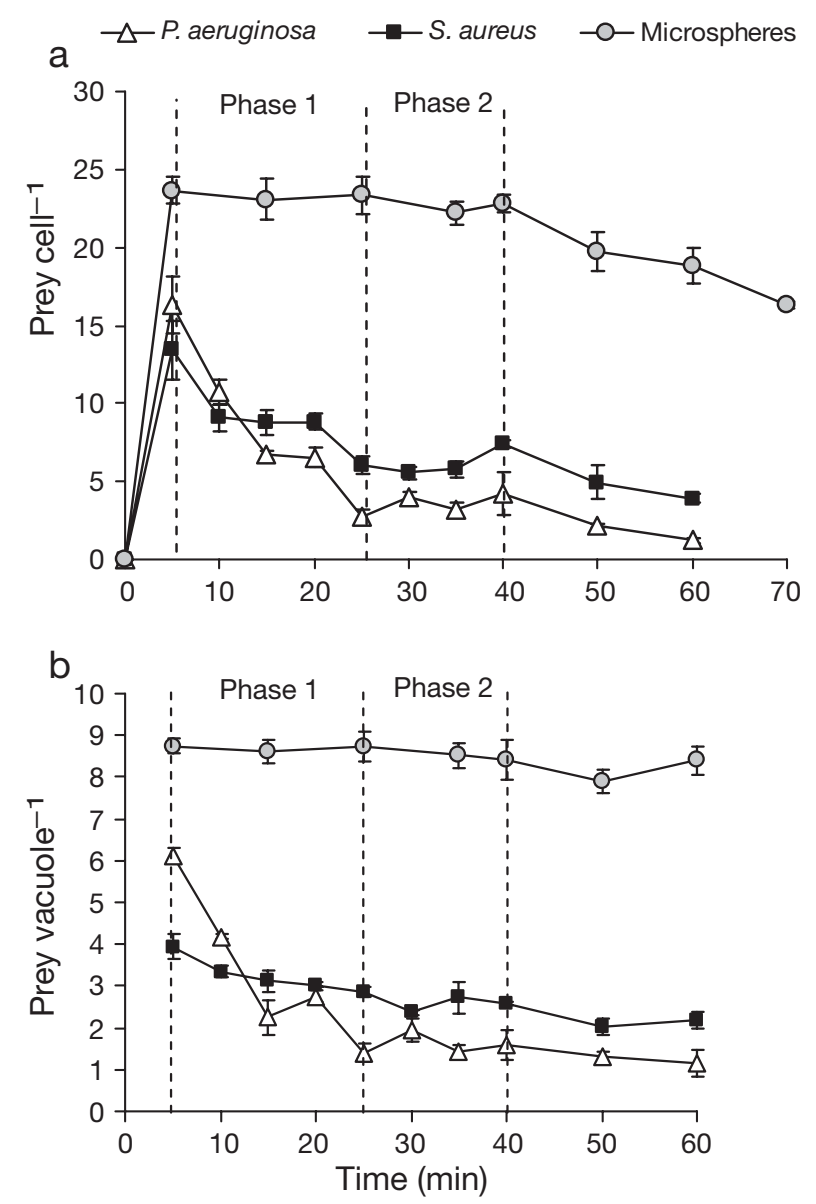

Fig. 3. Tetrahymena pyriformis. Pulse chase experiment showing loss of Staphylococcus aureus, Pseudomonas aeruginosa and microspheres from ciliates during a 40 min vacuole passage time. Prey concentrations were $1 \times 10^{7}, 1 \times 10^{9}$ and $2 \times$ $10^{7}$ prey $\mathrm{ml}^{-1}$ respectively. Two activity phases identified in the 5-40 min period (dashed vertical lines). Phase 1: linear loss in prey vacuole ${ }^{-1}(5-25 \mathrm{~min})$, Phase 2: (25-40 min) reduced rate of prey loss before start of egestion. (a) Number of prey ciliate ${ }^{-1}$. (b) Decline in prey vacuole ${ }^{-1}$. Error bars: SE

uniform; there was an initial linear loss of both $P$. aeruginosa and $S$. aureus until 25 or $30 \mathrm{~min}$, respectively (Fig. 3a). Beyond this, no loss of prey was evident. After $40 \mathrm{~min}$, the number of bacteria cell ${ }^{-1}$ began to decline again (Fig. 3a) and this coincided with the start of microsphere egestion, at the end of the VPT. This implies that, within a given experiment, VPT duration is independent of vacuolar content and is the same for vacuoles containing either digestible or indigestible prey. Presentation of the data in a different format, i.e. the loss of prey vacuole ${ }^{-1}$ over time (Fig. 3b), also confirmed that prey loss only occurred during the first 25 to $30 \mathrm{~min}$, after which, digestion was significantly reduced ( $p \leq 0.008)$. These data therefore suggest that digestion of prey occurs within a defined period of time during the life-span of a food vacuole in
T. pyriformis. Considering the shortest VPT recorded with this ciliate was $25 \mathrm{~min}$, we propose that the length of this digestive phase is 25 min (Phase 1, Fig. 3). After $\sim 25 \mathrm{~min}$, we consider the vacuoles to be inactive and awaiting egestion from the cell (Phase 2, Fig. 3). Thus, all future calculations of prey digestion rate in this study used only data from the chase to the end of the digestive period (25 $\mathrm{min}$ ), so the chase occurred early (at $5 \mathrm{~min}$ ) to allow $20 \mathrm{~min}$ worth of data for linear regression analysis.

\section{Effect of ciliate feeding history}

Tetrahymena pyriformis was pre-fed either live Mesorhizobium sp. (digestible and non-fluorescent), Synechococcus sp. or microspheres (both indigestible but fluorescent) for 5, 15 and 30 min prior to a pulse chase experiment where the digestion of fluorescent Mesorhizobium sp. cells was monitored. The control culture was not pre-fed. The length of the pre-feeding period gave rise to different numbers, and contents, of pre-existing food vacuoles in the ciliate cells prior to the pulse-chase experiment, but only those containing fluorescent prey could be enumerated (Table 2). A 5 min pre-feed gave rise to 1.5 to 2.2 pre-existing food vacuoles cell ${ }^{-1}$, while 30 min yielded 5.2 to 6.5 preexisting food vacuoles cell ${ }^{-1}$ (Table 2). The time at which the first of these fluorescent food vacuoles was lost from the cells yielded the VPT, i.e. $55 \mathrm{~min}$. This was also considered to be the VPT of cells pre-fed with invisible Mesorhizobium sp. cells.

These pre-fed cells were immediately pulsed for 5 min with fluorescent Mesorhizobium sp. cells, chased and then digestion rates (prey vacuole ${ }^{-1} \mathrm{~min}^{-1}$ ) determined over a $25 \mathrm{~min}$ period (Fig. 4: begins at $5 \mathrm{~min}$, the point of dilution). The first point to note is that the 3 prefeeding regimes did not alter the rate at which food vacuoles were formed (Table 2), but vacuoles of pre-fed cells contained significantly more fluorescent Mesorhizobium sp. cells than non pre-fed cells (control) (Fig. 4, Table 2). Secondly, no matter what the ciliate had been pre-fed with or the duration of the pre-feeding, there was an immediate loss of fluorescent Mesorhizobium sp. within the food vacuoles (Fig. 4) suggesting that newly formed food vacuoles are immediately presented with digestive machinery, i.e. fusion with acidosomes and lysosomes. Thirdly, the digestion rates of fluorescent Mesorhizobium sp. were equivalent in all ciliate cultures except for those pre-fed with an indigestible prey for $30 \mathrm{~min}$ (Table 2). These were significantly higher $(\mathrm{p} \leq 0.01)$ due to a 'burst' of rapid digestion over the first $5 \mathrm{~min}$ (Fig. 4a,b), suggesting that an elevated level of digestive machinery was being presented to new vacuoles after 30 min of starvation. 
Table 2. Tetrahymena pyriformis. Ingestion and digestion rates \pm SE of DTAF-stained Mesorhizobium sp. (fluorescently-labeled bacterium: FLB) following 10 different pre-treatments. Fluorescent bacterium was incubated with the ciliate at $2 \times 10^{7} \mathrm{prey}^{-1}$ for 5 min before dilution. ${ }^{*} \mathrm{p}<0.05$ : significantly different from control (no pre-feeding). ND: not determined

\begin{tabular}{|c|c|c|c|c|c|c|c|}
\hline \multirow{2}{*}{$\begin{array}{l}\text { Initial prey } \\
\text { type }\end{array}$} & \multicolumn{2}{|c|}{ _ Feeding history __ } & \multirow{2}{*}{$\begin{array}{l}\text { Time of } \\
\text { observed } \\
\text { egestion } \\
\text { (min) }\end{array}$} & \multicolumn{4}{|c|}{ _ Processing of DTAF-stained Mesorhizobium cells (FLB) } \\
\hline & $\begin{array}{l}\text { Incubation } \\
\text { time (min) }\end{array}$ & $\begin{array}{c}\text { No. of } \\
\text { vacuoles } \\
\text { cell }^{-1}\end{array}$ & & $\begin{array}{l}\text { No. of FLB } \\
\text { ingested cell }^{-1} \\
\text { in } 5 \mathrm{~min}\end{array}$ & $\begin{array}{l}\text { No. of FLB } \\
\text { vacuoles cell } \\
\text { in } 5 \mathrm{~min}\end{array}$ & $\begin{array}{l}\text { No. of FLB } \\
\text { vacuole }^{-1}\end{array}$ & $\begin{array}{c}\text { Initial rate of } \\
\text { FLB loss (prey } \\
\text { vacuole }^{-1} \mathrm{~min}^{-1} \text { ) }\end{array}$ \\
\hline Synechococcus & 30 & $6.5 \pm 0.3$ & 55 & $20.2 \pm 1.5^{*}$ & $2.3 \pm 0.1$ & $8.88 \pm 0.5^{*}$ & $0.161 \pm 0.005^{*}$ \\
\hline Synechococcus & 15 & $5.4 \pm 0.3$ & 55 & $17.6 \pm 1.2^{*}$ & $2.5 \pm 0.1$ & $7.01 \pm 0.5^{*}$ & $0.127 \pm 0.013$ \\
\hline Synechococcus & 5 & $2.2 \pm 0.1$ & 55 & $22.0 \pm 1.1^{*}$ & $2.9 \pm 0.2$ & $7.65 \pm 0.1^{*}$ & $0.135 \pm 0.016$ \\
\hline Microspheres & 30 & $5.2 \pm 0.3$ & 55 & $20.6 \pm 1.4^{*}$ & $2.7 \pm 0.1$ & $7.83 \pm 0.2^{*}$ & $0.165 \pm 0.018^{*}$ \\
\hline Microspheres & 15 & $3.6 \pm 0.4$ & 55 & $18.1 \pm 0.7^{*}$ & $2.6 \pm 0.1$ & $7.02 \pm 0.2^{*}$ & $0.133 \pm 0.014$ \\
\hline Microspheres & 5 & $1.5 \pm 0.1$ & 55 & $15.5 \pm 0.5$ & $2.5 \pm 0.1$ & $5.74 \pm 0.2^{*}$ & $0.112 \pm 0.013$ \\
\hline Mesorhizobium & 30 & ND & ND & $13.8 \pm 0.9$ & $2.5 \pm 0.2$ & $5.33 \pm 0.1^{*}$ & $0.082 \pm 0.007$ \\
\hline Mesorhizobium & 15 & ND & ND & $16.2 \pm 0.5^{*}$ & $2.9 \pm 0.2$ & $5.40 \pm 0.2^{*}$ & $0.081 \pm 0.005$ \\
\hline Mesorhizobium & 5 & ND & ND & $14.0 \pm 0.7$ & $2.5 \pm 0.2$ & $5.50 \pm 0.3^{*}$ & $0.098 \pm 0.005$ \\
\hline No treatment & 0 & 0 & ND & $10.7 \pm 0.7$ & $2.7 \pm 0.2$ & $3.64 \pm 0.2$ & $0.090 \pm 0.003$ \\
\hline
\end{tabular}
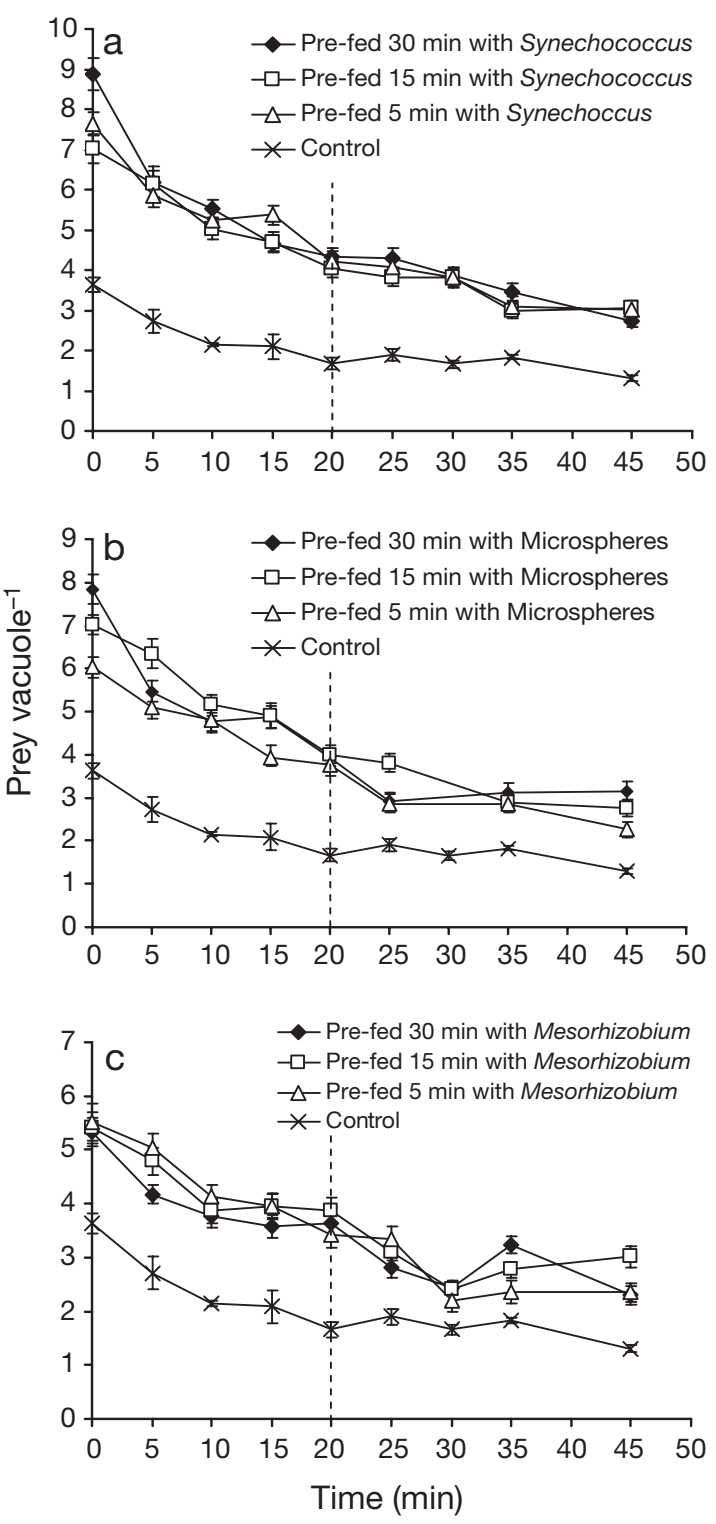

\section{Rates of bacterial prey digestion}

Tetrahymena pyriformis was presented with 6 different prey ( 2 indigestible and 4 potentially digestible) (Fig. 5a) and the ingestion rates for all prey were equal, except for Synechococcus sp., which was ingested at a significantly faster rate $(p<0.009)$ (Table 3$)$. The 1:200 dilution at 5 min reduced further ingestion of fluorescent prey, and residual ingestion did not yield rates which significantly changed the data. The number of microspheres and Synechococcus sp. cells ciliate $^{-1}$ remained level between 5 and 30 min (Fig. 5a) indicating a VPT of $30 \mathrm{~min}$. The number of bacteria vacuole $^{-1}$ declined linearly from 5 to $\sim 25 \mathrm{~min}$ (Fig. 5b), and the rates of digestion for Escherichia coli K12, Mesorhizobium sp. and Pseudomonas aeruginosa (Gram negative bacteria) were not significantly different from each other but were significantly faster than for Staphylococcus aureus (Gram positive bacterium) $(\mathrm{p}<0.05)$, which was hardly digested at all (Table 3$)$.

\section{Classification of prey digestibility}

Fig. 6 shows examples of the persistence of fluorescent prey ciliate ${ }^{-1}$ and fluorescent vacuoles ciliate ${ }^{-1}$ from the chase (at $5 \mathrm{~min}$ ) to the end of the VPT, which was $35 \mathrm{~min}$ (Fig. 6 a,c) or $50 \mathrm{~min}$ (Fig. 6b), as determined with microspheres (data not shown). Fig. 6a

Fig. 4. Tetrahymena pyriformis. Loss of DTAF-stained Mesorhizobium sp. cells vacuole ${ }^{-1}$ after the second dilution $(t=0)$ when the ciliate was not pre-fed (control) and pre-fed with (a) Synechococcus sp., (b) microspheres and (c) Mesorhizobium sp. for 5, 15 and $30 \mathrm{~min}$. Dashed line indicates end of Phase 1 
shows that Synechococcus sp. cells ciliate ${ }^{-1}$ and fluorescent vacuoles ciliate ${ }^{-1}$ remained constant throughout the VPT, indicating that this prey was ND during one VPT. Fig. $6 \mathrm{~b}$ shows that Mesorhizobium sp. cells
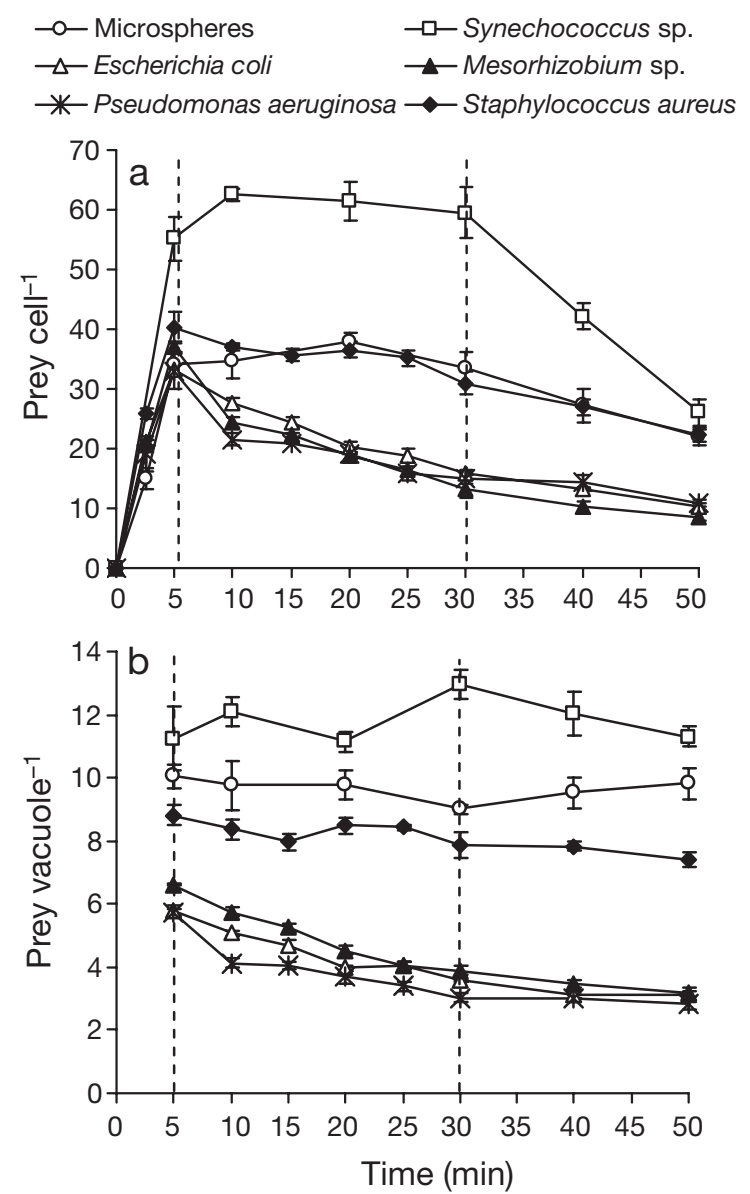

Fig. 5. Tetrahymena pyriformis. Loss of prey within 1 vacuole passage time. Initial concentration of all prey types $=2 \times 10^{8}$ prey $\mathrm{ml}^{-1}$. At $5 \mathrm{~min}$, suspensions were diluted 1:200. Digestion is identified between the point of dilution and the start of microsphere and Synechococcus sp. egestion at 30 min (hashed lines). (a) Number of prey ciliate ${ }^{-1}$, (b) shows decline of prey vacuole $^{-1}$ from 5 min. Error bars: SE ciliate $^{-1}$ declined, but the number of fluorescent vacuoles ciliate ${ }^{-1}$ remained constant, indicating that the vacuolar contents were only PD within 1 VPT. Finally, Fig. 6c shows a loss in both Mesorhizobium sp. cells ciliate $^{-1}$ and fluorescent vacuoles ciliate ${ }^{-1}$, indicating TD of vacuolar contents within 1 VPT. In the latter 2 examples, the ingestion of a single prey species resulted in 2 classifications, i.e. PD and TD. The main difference between these 2 experiments was that at $5 \mathrm{~min}$, the ciliate food vacuoles in one system (Fig. 6b) contained $\sim 11$ prey while those in the other system (Fig. 6c) contained $\sim 5$. The effect of prey vacuole ${ }^{-1}$ on digestibility was examined further using this classification scheme (Fig. 7), and results suggest that there is increased likelihood that all vacuole-enclosed cells are digested if the average number of prey vacuole ${ }^{-1}$ is $\sim 6$ or below. Despite various attempts with very high concentrations of Pseudomonas aeruginosa, food vacuole content never exceeded $\sim 6$ cells per vacuole, therefore, complete digestion always occurred. Conversely, attempts to achieve <6 Synechococcus sp. cells vacuole $^{-1}$ failed, so this prey type was always recorded as never being digested.

\section{DISCUSSION}

Protozoa are known to be major grazers of bacteria in aquatic environments, yet only factors that affect prey ingestion have been thoroughly examined to date (Montagnes et al. 2008). Far less is known about the post-ingestion phase even though some studies have indicated that differential digestion might be just as influential as selective ingestion in shaping the nature of bacterial communities (Sherr et al. 1988, González et al. 1990, 1993, Iriberri et al. 1994).

The present study examined the post-ingestion phase of Tetrahymena pyriformis and proposes that food vacuole processing is orderly and that egestion proceeds at a defined, linear rate from a single site, i.e.

Table 3. Tetrahymena pyriformis. Comparison of ingestion, vacuole formation and digestion rates, as prey loss vacuole $\mathrm{min}^{-1}$ $( \pm \mathrm{SE})$ for the ciliate feeding on 6 prey types (at $2 \times 10^{8}$ prey $\mathrm{ml}^{-1}$ ) and chased at 5 min with a 1:200 dilution. Prey loss vacuole ${ }^{-1}$ are net values after correcting for non-digestible prey loss over $25 / 30 \mathrm{~min} .{ }^{*} \mathrm{p}<0.05$

\begin{tabular}{|c|c|c|c|c|c|c|}
\hline Prey & $\begin{array}{l}\text { Biovolume } \\
\qquad\left(\mu \mathrm{m}^{3}\right)\end{array}$ & $\begin{array}{c}\text { Ingestion rate } \\
\left(\text { prey cell }^{-1} \min ^{-1} \text { ) }\right.\end{array}$ & $\begin{array}{l}\text { Average prey } \\
\text { cell }^{-1} \text { (at } 5 \mathrm{~min} \text { ) }\end{array}$ & $\begin{array}{l}\text { Vacuole formation } \\
\text { rate }(\text { vacuole } \\
\left.\text { cell }{ }^{-1} \mathrm{~min}^{-1}\right)\end{array}$ & $\begin{array}{l}\text { Average vacuole } \\
\text { cell }^{-1} \text { (at } 5 \mathrm{~min} \text { ) }\end{array}$ & $\begin{array}{c}\text { Prey loss } \\
\text { (prey vacuole } \\
\text { min }^{-1} \text { ) }\end{array}$ \\
\hline E. coli $\mathrm{K} 12$ & $0.20 \pm 0.03$ & $6.63 \pm 0.19$ & $33.17 \pm 0.97$ & $1.15 \pm 0.01$ & $5.77 \pm 0.13$ & $0.116 \pm 0.010$ \\
\hline Mesorhizobium sp. & $0.17 \pm 0.01$ & $7.42 \pm 0.16$ & $37.09 \pm 0.81$ & $1.15 \pm 0.03$ & $5.75 \pm 0.13$ & $0.114 \pm 0.010$ \\
\hline$P$. aeruginosa & $0.27 \pm 0.01$ & $6.59 \pm 0.56$ & $32.97 \pm 2.82$ & $1.18 \pm 0.05$ & $5.88 \pm 0.14$ & $0.091 \pm 0.015$ \\
\hline S. aureus & $0.31 \pm 0.02$ & $8.09 \pm 0.28$ & $40.35 \pm 2.69$ & $0.93 \pm 0.03$ & $4.63 \pm 0.13$ & $0.024 \pm 0.012$ \\
\hline Microspheres & $0.41 \pm 0.02$ & $6.81 \pm 0.41$ & $34.05 \pm 2.07$ & $0.65 \pm 0.01$ & $3.27 \pm 0.13$ & - \\
\hline Synechococcus sp. & $0.74 \pm 0.02$ & $10.07 \pm 0.53^{*}$ & $55.20 \pm 3.66$ & $1.07 \pm 0.05$ & $5.35 \pm 0.15^{*}$ & - \\
\hline
\end{tabular}


the cytoproct, for a given particle at a given temperature. Previous studies on prey/vacuole loss from protozoan cells have recorded both a linear decline (Sherr et al. 1988, González et al. 1990, 1993, González \& Suttle 1993, Hammer et al. 2001, Myung et al. 2006) and an exponential decline (Dolan \& Coats 1991, Dolan \& Šimek 1997, 1998, Jürgens \& Šimek 2000, Jezbera et al. 2005), with the latter implying that food vacuoles
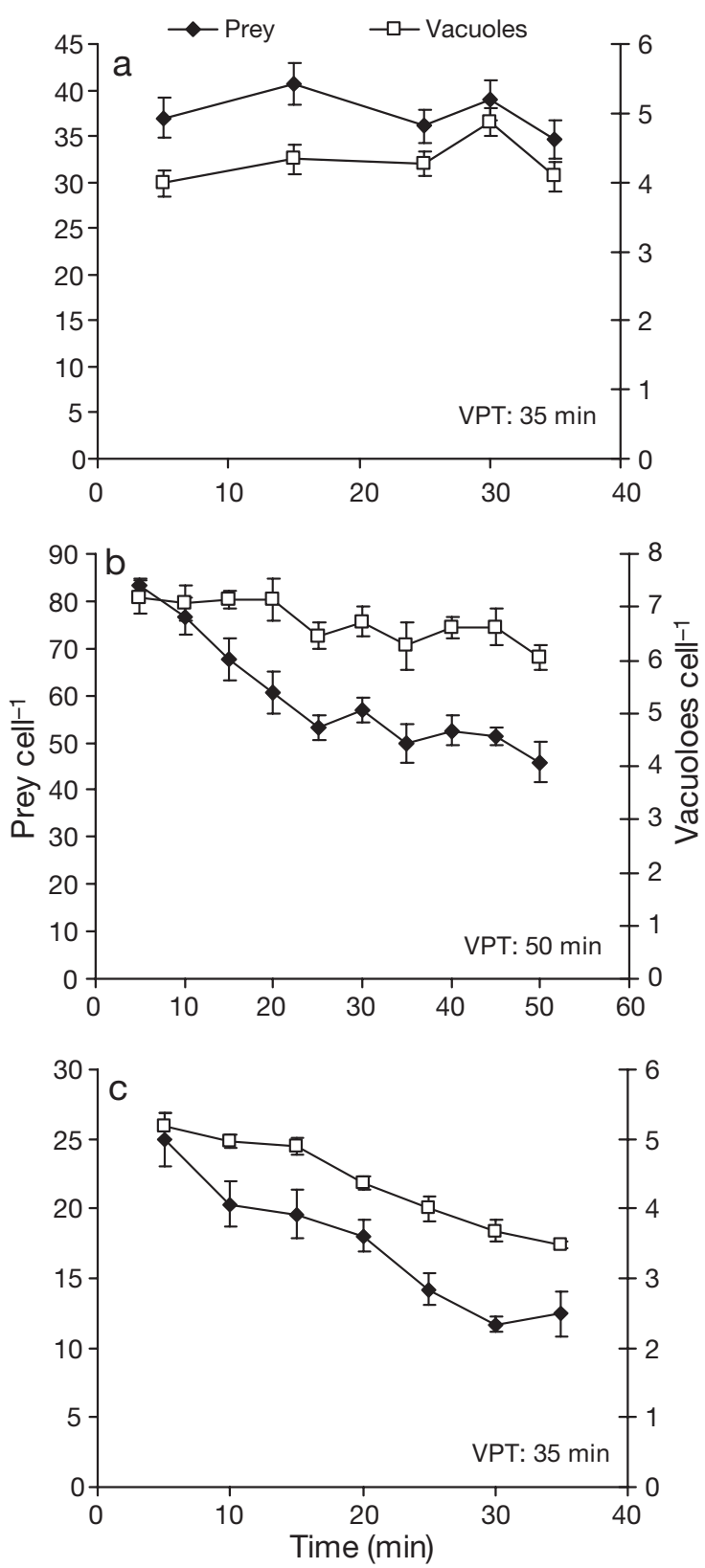

Fig. 6. Tetrahymena pyriformis. Prey classification depending upon prey and associated vacuole loss during vacuole passage time (VPT). (a) No digestion of prey (Synechococcus sp.) during a 35 min VPT. (b) Partial digestion of Mesorhizobium sp. during a 50 min VPT. (c) Total digestion of Mesorhizobium sp. during a 35 min VPT. Error bars: SE fuse together and are egested simultaneously (Dolan \& Coats 1991). Although vacuolar fusion has been observed in Euplotes woodruffi (Dolan \& Coats 1991) and E. vannus (Dolan \& Coats 2008), we have never observed this in T. pyriformis. In addition, the multiple chase experiment showed that vacuoles were 'egested' in the same order they were formed, suggesting that vacuole processing is orderly and there is no 'short circuiting' of the system. We do however acknowledge that loss of prey/vacuoles cell ${ }^{-1}$ may sometimes appear exponential, and propose that this is due to inherent variation in the feeding rates of individual cells within a given population: a feature reported in other shortterm feeding studies (Dolan \& Šimek 1997, Jürgens \& Šimek 2000, Dolan \& Coats 2008). For example, if by the time of the chase, $50 \%$ of the ciliate population contained 2 vacuoles and $50 \%$ contained 4 vacuoles, and if each cell 'egested' vacuoles in a linear manner, the rate of decline in vacuoles cell ${ }^{-1}$ for the population as a whole would be linear until all ciliate cells had 'egested' 2 vacuoles. After this, only $50 \%$ of the population would continue to 'egest' the remaining 2 vacuoles; thus, the average loss rate of vacuoles cell ${ }^{-1}$ for the population as a whole would be halved, giving the impression of an exponential decline. Thus, orderly, 'linear' egestion could give rise to both graphical forms. Orderly processing could also explain why the VPT of T. pyriformis cells varied between experiments: a feature which has been observed in other studies (Fok et al. 1982, 1984, Fok \& Shockley 1985). Although ciliate cultures were prepared in a consistent manner prior to experimentation, there could still be inherent variation with regards to the number of pre-existing food (invisible) vacuoles present within the cells. Thus, the observed variation in VPT might be governed by the extent to which fluorescent vacuoles (in the pulsechase experiment) have to queue behind invisible preexisting vacuoles before they are 'egested'.

Studies on Paramecium caudatum have shown that the defecation competent phase is variable whilst the digestive phase is fixed at $21 \mathrm{~min}$ (Fok et al. 1982, 1984). The present study concurs, with Tetrahymena pyriformis exhibiting a constant digestive phase of $\sim 25 \mathrm{~min}$, yet possessing a variable VPT. Our prey digestion rates were therefore calculated during this 25 min digestive period, but other studies have monitored prey loss after a prolonged pulse period, and observations have probably been made during times that exceeded both the digestive phase and the VPT of the protozoan concerned (Sherr et al. 1988, González et al. 1990, 1993, Dolan \& Coats 1991, González \& Suttle 1993, Dolan \& Šimek 1997, 1998, Gunderson \& Goss 1997, Jezbera et al. 2005, Myung et al. 2006). Their observed prey losses might therefore be due to a combination of both digestion and egestion. For example, Gunderson \& Goss (1997) moni- 


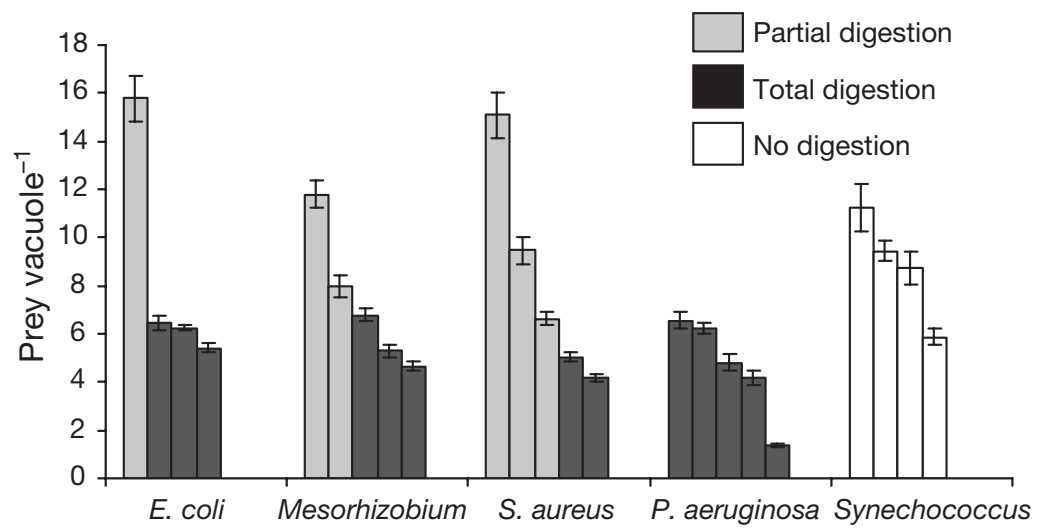

Fig. 7. Tetrahymena pyriformis. Effect of prey vacuole ${ }^{-1}$ on the extent of digestion within the food vacuole. Prey classified as either totally digested, partially digested or not digested. A higher number of prey vacuole ${ }^{-1}$ resulted in less complete digestion for each prey type with the exception of Synechococcus sp. which was not digestible. Error bars: SE

tored the disappearance of fluorescent Escherichia colicontaining food vacuoles from Tetrahymena sp. cells after a $3 \mathrm{~h}$ pulse phase at $25^{\circ} \mathrm{C}$. They observed a more rapid 'loss' of vacuoles within the first $30 \mathrm{~min}$, followed by a slower rate that continued for $90 \mathrm{~min}$. We can now interpret this first rate to be a result of both digestion and egestion of the prey, while the second rate is probably due to egestion only. This not only supports our findings of a 25 min digestive phase in Tetrahymena sp. food vacuoles, but also demonstrates that true digestion rates, and the duration of the digestion phase, can be determined from such data provided the frequency of data points is high enough, or the digestive phase is long enough, to discern the 2 rates. Using this rationale, we could, for example, propose that the digestive phase within food vacuoles of Halteria grandinella is $\sim 1 \mathrm{~h}$ based on the data presented in Fig. 2A by Jürgens \& Šimek (2000). This is slower than the 21 and $25 \mathrm{~min}$ recorded for $P$. caudatum (Fok et al. 1982, 1984) and $T$. pyrifomis (the present study), but experiments were performed at different temperatures $\left(16,25\right.$ and $23^{\circ} \mathrm{C}$, respectively), and temperature has been shown to affect the rate of food vacuole formation (Lee 1942) and digestion/egestion (Sherr et al. 1988). Temperature was maintained at $23^{\circ} \mathrm{C}$ for all experiments during the present study.

The duration of these digestive phases may appear short, but data suggest that for Tetraymena pyrifomis at least, newly formed food vacuoles are immediately presented with biochemical machinery for the digestion of prey. This agrees with the work of Mueller et al. (1965) who also found evidence for immediate digestion in T. pyriformis vacuoles, together with Paramecium multilicronucleatum, and with Peck \& Hausmann (1980) and Hausmann (2002) working with Pseudomi- crothorax dubious. The intensity of the presented digestive machinery, as measured by the digestion rate of Mesorhizobium sp. by T. pyriformis, appeared to be independent of ciliate feeding history except when cells were pre-fed an indigestible prey for $30 \mathrm{~min}$. In these cases, there was a 'burst' of rapid digestion of Mesorhizobium sp. over the first $5 \mathrm{~min}$ after the chase, suggesting that an elevated level of digestive machinery was being presented to new vacuoles after a period of induced starvation. There are 2 hypotheses that might explain how this was achieved. (1) There is evidence that the social amoeba Dictyostelium discoidium (Souza et al. 1997, Rupper et al. 2001) and macrophages (Oh \& Swanson 1996) can detect vacuolar content and make adjustments to vacuole trafficking, so in the present study digestive machinery might have been immediately re-directed from the vacuoles containing indigestible prey to those newer ones containing digestible prey. (2) Fok \& Paeste (1982) showed that levels of enzyme activity in 2 Paramecium spp. were increased under nutrient stress; thus, $T$. pyriformis may have up-regulated digestive enzyme activity in response to the prolonged feeding on indigestible prey. Both theories are currently being studied with $T$. pyriformis, but whatever the mechanism, results imply that that feeding history might significantly influence food vacuole processing and digestive efficiency. It would have been interesting to compare how other pre-feeding regimes, such as using different bacterial prey or an axenically-grown ciliate culture, might have affected vacuole processing, but although important, this was not in the remit of the current study and constitute future work.

When non-starved Tetrahymena pyriformis was presented with a range of prey, the 3 Gram negative bacteria were digested at equivalent rates. However, this may be an artefact of the method used to prepare these prey as they were all heat-killed and stained, making them more equivalent. Although Sherr et al. (1987) showed that stained prey could sustain protozoan growth rates equal to their unstained counterparts, other work has challenged this assumption (Landry et al. 1991, Parry et al. 2001), and stained Staphylococcus aureus cells have been shown to be more difficult to digest than their live counterpart in Paramecium sp. (Mehlis \& Hausmann 1990). It is fully anticipated that if the prey species tested here had been live, differential digestion might have been recorded, as demonstrated by Jezbera et al. (2005). However, for the present study, the use of heat-killed 
bacteria has allowed an evaluation of the duration of the digestive phase in T. pyriformis and the ciliate's ability to digest bacteria in the absence of an active bacterial response to resist digestion.

Only 1 Gram positive bacterium was included in this study (Staphylococcus aureus), but we could speculate that reduced digestion, compared to Gram negative strains, is attributed to differences in cell wall structure as suggested by Nilsson (1987), González et al. (1990) and Iriberri et al. (1994), with Gram positive cell walls being thicker than those of Gram negative cells. Synechoccocus cells, although Gram negative, have even thicker cell walls (Golecki 1977) and this may have contributed to their resistance to digestion, not only in T. pyriformis, but also in amoebae (Pickup et al. 2007, Dillon \& Parry 2009). Vacuoles containing <6 Synechococcus sp. cells vacuole ${ }^{-1}$ proved difficult to achieve, but if this had been possible, it may have changed the overall outcome of digestion, as observed with the other bacterial prey. With these, results suggest that if the number of prey vacuole ${ }^{-1}$ remained below a certain threshold ( 6), the enclosed bacteria were more likely to be digested. Above this threshold, digestion was less efficient and intact bacterial cells could be egested from the cell.

This latter observation demonstrates that bacterial cells do not necessarily require elaborate mechanisms to evade digestion in protozoan food vacuoles, as possessed by some pathogenic bacteria (e.g. Abu Kwaik et al. 1998). Inefficiency in the protozoan digestive system might be all that is required to allow the release of un-digested, 'apparently unharmed' prey from their cells. However, these emergent prey might possess different characteristics to their un-ingested counterparts, which would cause them to interact differently within the microbial food web. For example, emergent cells of pathogenic bacteria such as Legionella pneumophila possess an increased level of pathogenicity (Cirillo et al. 1994) and increased resistance to antimicrobials (Barker et al. 1992, 1995). Emergent cells of the nonpathogenic Escherichia coli K12 have been shown to possess different genotypes due to increased levels of conjugation in Tetrahymena pyriformis food vacuoles (Schlimme et al. 1997). More recently, it has been hypothesized that the acidic nature of protozoan food vacuoles induces temperate phage within lysogenised bacteria to enter the lytic cycle; thus, emergent cells would be in the irreversible process of cell lysis (Clarke 1998, Parry et al. 2006). These few examples show that interactions between protozoa and prey, at the food vacuole level, are complex. They deserve further investigation to elucidate how protozoan predators might enhance the survival, replication and distribution of bacteria in situ and contribute to bacterial succession and evolution. In addition, the potential inabil- ity of protozoa to digest every prey cell ingested has implications for carbon cycling, and those mathematical models that employ data on protistan ingestion rates alone should consider accounting for digestion efficiency and the subsequent effect of prey concentration, as prey carbon might not always be transferred efficiently to higher trophic levels.

Acknowledgements. This study was supported by the Natural Environment Research Council studentship NER/S/A/2003/ 11261 and the Wellcome Trust Grant No. F00130K. Thanks go to C. Dixon, R. W. Saunders and 2 anonymous reviewers for their constructive comments.

\section{LITERATURE CITED}

Abu Kwaik Y, Gao LY, Stone BJ, Harb OS (1998) Invasion of mammalian and protozoan cells by Legionella pneumophila. Bull Inst Pasteur 96:237-247

Allen RD, Fok AG (1980) Membrane recycling and endocytosis in Paramecium confirmed by horseradish peroxidase pulse-chase studies. J Cell Sci 45:131-145

> Azam F, Fenchel T, Field JG, Gray JS, Meyer-Reil LA, Thingstad F (1983) The ecological role of water-column microbes in the sea. Mar Ecol Prog Ser 10:257-263

Barker J, Brown MRW, Collier PJ, Farrell I, Gilbert P (1992) Relationship between Legionella pneumophila and Acanthamoeba polyphaga: physiological status and susceptibility to chemical inactivation. Appl Environ Microbiol 58: 2420-2425

Barker J, Scaife H, Brown MRW (1995) Intraphagocytic growth induces an antbiotic-resistant phenotype in Legionella pneumophila. Antimicrob Agents Chemother 39: 2684-2688

Cirillo JD, Falkow S, Tompkins LS (1994) Growth of Legionella pneumophila in Acanthamoeba castellanii enhances invasion. Infect Immun 62:3254-3261

Clarke KJ (1998) Virus like production in lysogenic bacteria exposed to protozoan grazing. FEMS Microbiol Lett 166: $177-180$

Dillon A, Parry JD (2008) Characterization of temperate cyanophages active against freshwater phycocyanin-rich Synechococcus species. Freshw Biol 53:1253-1261

Dillon A, Parry JD (2009) Amoebic grazing of freshwater Synechococcus strains rich in phycocyanin. FEMS Microbiol Ecol 69:106-112

Dolan JR, Coats WD (1991) Preliminary digestion data in the predacious estuarine ciliate and the use of digestion data to estimate ingestion. Limnol Oceanogr 36:558-565

Dolan JR, Coats WD (2008) Physiological diversity in widely distributed microzooplankton: digestion in the ciliate Euplotes vannus. In: Dijk TV (ed) Microbial ecology research trends. Nova Science, Hauppauge, NY, p 207-220

Dolan JR, Šimek K (1997) Processing of ingested matter in Strombidium sulcatum, a marine ciliate (Oligotrichida). Limnol Oceanogr 42:393-397

Dolan JR, Šimek K (1998) Ingestion and digestion of an autotrophic picoplankter, Synechococcus, by a heterotrophic nanoflagellate, Bodo saltans. Limnol Oceanogr 43: $1740-1746$

Eccleston-Parry JD, Leadbeater BSC (1994) A comparison of the growth kinetics of six marine heterotrophic nanoflagellates fed with one bacterial species. Mar Ecol Prog Ser 105:167-177

Fok AK, Paeste RM (1982) Lysosomal enzymes of Paramecium 
caudatum and Paramecium tetraurelia. Exp Cell Res 139: $159-169$

Fok AK, Shockley BU (1985) Processing of digestive vacuoles in Tetrahymena and the effects of Dichloroisoproterenol. J Protozool 32:6-9

Fok AK, Lee Y, Allen RD (1982) The correlation of digestive vacuole $\mathrm{pH}$ and size with the digestive cycle in Paramecium caudatum. J Protozool 29:409-414

Fok AK, Muraoka JH, Allen RD (1984) Acid phosphatase in the digestive vacuole and lysosomes of Paramecium caudatum: a timed study. J Protozool 31:216-220

- Golecki JR (1977) Studies on ultrastructure and composition of cell walls of the cyanobacterium Anacystis nidulans. Arch Microbiol 114:35-41

González JM, Suttle CA (1993) Grazing by marine nanoflagellates on viruses and virus-sized particles: ingestion and digestion. Mar Ecol Prog Ser 94:1-10

González JM, Iriberri J, Egea L, Barcina I (1990) Differential rates of digestion of bacteria by freshwater and marine phagotrophic protozoa. Appl Environ Microbiol 56: 1851-1857

González JM, Sherr EB, Sherr BF (1993) Differential feeding by marine flagellates on growing versus starving, and on motile versus nonmotile bacterial prey. Mar Ecol Prog Ser 102:257-267

Gunderson JH, Goss SH (1997) Fluorescently-labeled oligonucleotide probes can be used to identify protistan food vacuole contents. J Eukaryot Microbiol 44:300-304

Hammer A, Gruttner C, Schumann R (2001) New biocompatible tracer particles: use for estimation of microzooplankton grazing, digestion and growth rates. Aquat Microb Ecol 24:153-161

Hausmann K (2002) Food acquisition, food ingestion and food digestion by protozoa. Jpn J Protozool 35:85-95

> Hellung-Larsen P, Assaad F, Pankratova S, Saietz BL, Skovgaard LT (2000) Effects of Pluronic F-68 on Tetrahymena cells: protection against chemical and physical stress and prolongation of survival under toxic conditions. J Biotechnol 76:185-195

Iriberri J, Azua I, Labirua-Iturburu A, Artolozaga I, Barcina I (1994) Differential elimination of enteric bacteria by protists in a freshwater system. J Appl Bacteriol 77:476-483

Jezbera J, Hornák K, Šimek K (2005) Food selection by bacterivorous protists: insight from the analysis of the food vacuole content by means of fluorescence in situ hybridization. FEMS Microbiol Ecol 52:351-363

Johannes RE (1964) Phosphorus excretion and body size in marine animals: microzooplankton and nutrient regeneration. Science 146:923-924

Jürgens K, Šimek K (2000) Functional response and particle size selection of Halteria cf. grandinella, a common freshwater oligotrichous ciliate. Aquat Microb Ecol 22:57-68

Landry MR, Lehner-Fournier JM, Sunderstom JA, Fagerness VL, Selph KE (1991) Discrimination between living and heat-killed prey by a marine zooflagellate Paraphysomonas imperforata (Stokes). J Exp Mar Biol Ecol 146: 139-151

Lee JW (1942) The effect of temperature on food-vacuole formation in Paramecium. Physiol Zool 15:453-458

Mehlis I, Hausmann K (1990) Rapid digestion of Staphylococcus aureus by Paramecium: an evaluation of the role of bacterial autolytic enzymes. Eur J Protistol 26:103-109

- Montagnes DJS, Barbosa AB, Boenigk J, Davidson K and others (2008) Selective feeding behaviour of key free-living protists: avenues for continued study. Aquat Microb Ecol $53: 83-98$
Mueller M, Röhlich P, Törö I (1965) Studies on feeding and digestion in protozoa. VII. Ingestion of polystyrene latex particles and its early effect on acid phosphatase in Paramecium multilicronucleatum and Tetrahymena pyriformis. J Protozool 12:27-34

Myung G, Yih W, Kim HS, Park JS, Cho BC (2006) Ingestion of bacterial cells by the marine photosynthetic Myrionecta rubra. Aquat Microb Ecol 44:175-180

Nilsson JR (1987) Structural aspects of digestion of Escherichia coli in Tetrahymena. J Protozool 34:1-6

> Oh YK, Swanson JA (1996) Different fates of phagocytosed particles after delivery into macrophage lysosomes. J Cell Biol 132:585-593

Parry JD, Heaton K, Drinkall J, Jones HLJ (2001) Feasibility of using GFP-expressing Escherichia coli, coupled with fluorimetry, to determine protozoan ingestion rates. FEMS Microbiol Ecol 35:11-17

Parry J, Thurman J, Drinkall J, Dillon A (2006) Do phage and protozoa cooperate to digest freshwater picocyanobacteria? 11th Int Symp Microb Ecol (ISME-11), Vienna, 20-25 August 2006

Peck RK, Hausmann K (1980) Primary lysosomes of the ciliate Pseudomicrothorax dubious: cytochemical identification and role in phagocytosis. J Protozool 32:501-508

> Pickup ZL, Pickup R, Parry JD (2007) Effects of bacterial prey species and their concentration on growth of the amoeba Acanthamoeba castellanii and Hartmannella vermiformis. Appl Environ Microbiol 73:2631-2634

Porter KG, Feig YS (1980) The use of DAPI for identifying and counting aquatic microflora. Limnol Oceanogr 25:943-948

Rupper A, Grove B, Cardelli J (2001) Rab7 regulates phagosome maturation in Dictyostelium. J Cell Sci 114: $2449-2460$

Sanders RW, Porter KG, Bennett SJ, DeBiase AE (1989) Seasonal patterns of bacterivory by flagellates, ciliates, rotifers and cladocerans in a freshwater planktonic community. Limnol Oceanogr 34:673-687

Schlimme W, Baur B, Hanselmann K, Jenni B (1995) An agarose slide method to follow the fate of bacteria within digestive vacuoles. FEMS Microbiol Lett 133:169-173

Schlimme W, Marchiani M, Hanselmann K, Jenni B (1997) Gene transfer between bacteria within digestive vacuoles of protozoa. FEMS Microbiol Ecol 23:239-247

Sherr BF, Sherr EB, Fallon RD (1987) Use of monodispersed, fluorescently labeled bacteria to estimate in situ protozoan bacterivory. Appl Environ Microbiol 53:958-965

Sherr BF, Sherr EB, Rassoulzadegan F (1988) Rates of digestion of bacteria by marine phagotrophic protozoa: temperature dependence. Appl Environ Microbiol 54:1091-1095

Souza GM, Mehta DP, Lammertz M, Rodriguez-Paris J, Wu R, Cardelli JA, Freeze HH (1997) Dictyostelium lysosomal proteins with different sugar modifications sort functionally distinct compartments. J Cell Sci 110:2239-2248

> Stanier RY, Kunisawa R, Mandel M, Cohen-Bazire G (1971) Purification and properties of unicellular blue-green algae (Order Chroococcales). Bacteriol Rev 35:171-205

Strahl ED, Gillaspy EG, Falkinham JO III (2001) Fluorescent acid-fast microscopy for measuring phagocytosis of Mycobacterium avium, Mycobacterium intracellulare, and Mycobacterium scrofulaceum by Tetrahymena pyriformis and their intracellular growth. Appl Environ Microbiol 67: 4432-4439

Verni F, Gualtier P (1997) Digestive process of the raptorial feeder ciliate Litonotus lamella (Rabdophora, Litostomatea) visualized by fluorescence microscopy. Micron 28:447-451 